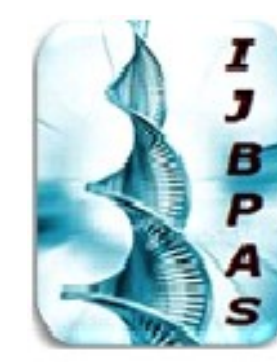

\author{
International Journal of Biology, Pharmacy \\ and Allied Sciences (IJBPAS) \\ 'A Bridge Betusen Caboratory and Q Qnendo'
}

WWW.iibpas.com

\title{
DEVELOPMENT AND EVALUATION OF CALOTROPIS GIGANTEALINN, ANTIFUNGAL TOPICAL FORMULATION
}

\section{MESHRAM $\mathbf{N}^{* 1}$, THAKARE $\mathbf{V}^{1}$ AND DHUMAL $\mathbf{J}^{2}$}

1: Department of Pharmaceutical Quality Assurance, Dadasaheb Balpande College of Pharmacy, Besa, Nagpur, (440037) India

2: Rajmata Jijau Shikshan Prasarak Mandal's College of Pharmacy, Dudulgaon (412105), Pune, Maharashtra, India

*Corresponding Author: Dr. V. M. Thakare; E Mail: vmthakre@gmail.com

Received $25^{\text {th }}$ April 2021; Revised $24^{\text {th }}$ June 2021; Accepted $30^{\text {th }}$ July 2021; Available online $1^{\text {st }}$ Oct. 2021

\section{https://doi.org/10.31032/IJBPAS/2021/10.10.1030}

\begin{abstract}
Objectives: To determine the nature of phytoconstituents present in Calotropis gigantea Linn, plant extracts. Evaluate the potential of Calotropis Gigantea, plant extracts for Anti-Fungal Activity and Preparation \& evaluation of anti-tuberculosis herbal formulation. Methodology: Calotropis gigantea plant extract which is successively extracted in various non-polar to polar solvents. Performing preliminary phytochemical for Calotropis gigantea plant extract. Perform TLC \& comparative TLC for methanolic extract. Flavonoid content phenolic content and antioxidant activity were performed with methanolic extract. And perform comparative microbial test of Calotropis Gigantea, plant extract in various strains. Formulations were prepared and perform evaluation parameter.

Results: Calotropis Gigantea, plant extract showed the maximum presence of secondary metabolites in methanolic extract. The total flavonoid content were found to be $7.10 \pm 0.141$ and $8.89 \pm 0.677 \mathrm{mg}$ of $\mathrm{QE} / \mathrm{g}$ in methanol extract and total phenolic content was found to be $6.78 \pm 0.036$ and $8.56 \pm 1.69 \mathrm{mg}$ of GA/g in methanol extract and Calotropris gigantea, plant extract showed significant antioxidant activity in methanolic extract.The comparative microbial study with fungi and bacteria shows good results against Candida albicans and thus herbal topical formulation of Calotropis gigantea, extractcan be used to treat Candidiasis. Conclusion: From this study, we concluded that Calotropis Gigantea, plant Extracts have potent Antifungal activity.
\end{abstract}

Keywords: Anti-fungal, Calotropis gigantea Linn, methanolic extract, microbial, Candida albicans 


\section{INTRODUCTION}

C.gigantea (Asclepiadaceae) is a perennial herb with a long history of use in traditional medicines. A wide range of chemical compounds including cardiac glycosides, flavonoids, terpenoids, alkaloids, tannins, \& resins has been isolated from this plant. The plant has been used for various disease condition including leprosy, ulcers, tumors and piles [1]. Various pharmacological activities reported like analgesic activity, antipyretic activity, pregnancy interceptive activity, CNS activity, anti-inflammatory activity, procoagulant activity, antidiarrhoeal activity, free radical scavenging activity, antimicrobial activity, anti-tumor activity, antifungal activity, antitussive activity, and antifeedant activity [2].

It is also used as an antispasmodic, antiasthematic, externally used for piles, Boils, ulcers, scabies, eczema, leprosy. It is also having anti-fungal activity, this activity search and performed scientifically, but the formulations are not prepared or documented [3].

\section{Anti-microbial Activities:}

The aqueous extract of leaves of C. gigantea was reported to possess antibacterial activity against Staphylococcus aureus, Escherichia coli, Bacillus cereus, Pseudomonas aeruginosa, Micrococcus luteus and Klebsiella pneumonia. The aqueous extract of the latex of C. gigantea was reported to exhibit significantly inhibitory effect on $S$. aureus, B. cereus, E. coli and C. krusei. 17 Antifungal activity of $C$. gigantea was reported against plant pathogenic fungi like Fusarium Mangifera, that causes serious threat in mango cultivation $[3,4]$.

\section{CANDIDA ALBICANS:}

Candida is thin walled small yeast that associates with humans as commensal and/or as pathogen. Candida is usually an opportunistic pathogen and can cause disease in humans, especially in immunocompromised patient. Nearly 150 species of Candida have been identified, out of them $C$. albicans is one of the most pathogenic species and it cause candidiasis. C. krusei, C. tropicalis, C. dubliniensis, C. parapsilosis etc. are some other pathogenic species from genus Candida. Most Candida infections can be treated topical administration of antifungal drugs such as clotrimazole, miconazole, nystatin, tioconazole or oral administration of drugs such as fluconazole and amphotericin B [5, 6].

Knowingly the Calotropis gigantea has the Anti-fungal Activity, so the its is aim to formulate the Anti-fungal formulation for the C.albicans Infection which is wide spread problem for the many of patients.

\section{MATERIALS AND METHODS:}


The Various materials used in research study was Calotropis gigantea Linn, procured from Dadasaheb Balpaned College Medicinal garden Nagpur region, Petroleum ether, Ethyl acetate, Ethanol, Methanol, Folinciocalteu and Borontrifluride reagent were procured from LOBA chemie, Mumbai. India. The Gallic acid obtained from SunCHEM, DPPH obtained from Sisco research laboratory Mumbai. India.

\section{COLLECTION \& AUTHENTICATION:}

Calotropis gigantea, Wight belonging to family Asclepiadaceae, thereFruits, were collected in month of august from native Nagpur region, Maharashtra (India) and authenticated from botanical department RTM Nagpur University India. The voucher specimen (No.10420) The leaves, stem and flowers were cut and dried at controlled temperature $45^{\circ} \mathrm{C}$.

\section{PREPARATION OF EXTRACT: [7]}

The dried coarse powder of Calotropis Gigantea Linn,plant was taken into in a Soxhlet apparatus. It was extracted successively by using non-polar to polar solvents. After completion of extraction, the extract was filtered and evaporated finally to obtain a crude extract.

\section{PRELIMINARY PHYTOCHEMICAL SCREENING: [8-10]}

The extracts of Calotropis gigantea, plant were subjected to different chemical tests for the detection of various present phytoconstituents like flavonoids, carbohydrates, glycosides, alkaloids, proteins, tannins and phenol. The screening techniques will be a valuable aid.

\section{TLC FINGERPRINTING: [11]}

Methanolic Calotropis Giganteaplant extract were subjected to qualitative phytochemical analysis of TLC. To conform the secondary metabolite in the extracts by using silica gel-G as a stationary phase for separate phytochemical compounds. Extract were spotted to prepared plate manually by using capillary and put into suitable mobile phase. After separation of phytochemical was seen by spraying various visualizing agent, UV light or iodine chamberand compare with stranded drug.

\section{DETERMINATION OF TOTAL}

\section{PHENOLIC CONTENT: $[12,13]$}

Total phenol content of Calotropis Gigantea methanolic extracts was determined by using modified Folin-Ciocalteau method. Absorbance of the test sample was measured at $\lambda \max =765 \mathrm{~nm}$. Total phenolic content was expressed as (mg of GAE/g of gallic acid) equivalent using the following linear regression equation based on the calibration curve: $\left(r^{2}=0.9989\right), y=0.0057 x$ +0.0113 , where $\mathrm{x}$ stands for absorbance and y stand for gallic acid equivalent (mg/g).

DETERMINATION OF TOTAL

FLAVONOIDS CONTENT: [13] 
The total flavonoid content of Calotropis gigantea, methanolic extract was determined by the aluminium chloride colorimetric method. Absorbance was measured at $510 \mathrm{~nm}$ and yellow colour indicated the presence of flavonoids. Total flavonoid content was calculated as quercetin (mg of $\mathrm{QE} / \mathrm{g}$ ) using the following equation based on the calibration curve: $\left(r^{2}\right.$ $=0.997), \mathrm{y}=0.0077 \mathrm{x}+0.0149$, where $\mathrm{x}$ stands for absorbance and $y$ stand for quercetin equivalent $(\mathrm{mg} / \mathrm{g})$.

\section{ANTIOXIDANT ACTIVITY (DPPH}

RADICAL SCAVENGING ASSAY): [14]

The absorbance of the sample was measured in spectrophotometrically at $\lambda \max =517 \mathrm{~nm}$. Ascorbic acid was used as standard. Percentages scavenging of DPPH of test extract were calculated by comparing the absorbance between the test mixture and control Percentage scavenging of DPPH was calculated by using formula.

$\%$ scavenging of DPPH $=($ Acontrol Atest) $/$ Acontrol $\times 100$

where; Abs Control is the absorbance of DPPH radical methanol; Abs Sample is the absorbance of DPPH radical + sample extract/standard.

FTIR INTERPRETATION OF PRESENT COMPOUND: [15]

The extract of C.Gigantea is dried in oven, and removal of moisture in Desiccator for a weeks,and after the sample get dried the $\mathrm{mg}$ quantity of sample is used with $\mathrm{KBr}$ analytical powder, to identify under Infrared red light source. And the peaks are identify under the range $4000^{-1}$ to $400^{-1}$.

FORMULATION OF CREAM: [16, 17] METHOD OF PREPARATION OF CREAM:

The formulation of $10 \% \mathrm{w} / \mathrm{v}$ prepared under the I.P, Melted the white wax and spermaceti on a hot plate. Added the mineral oil to this mixture and the temperature was maintained to $70^{\circ} \mathrm{C}$. Dissolved the sodium borate in water. Heated the sodium borate solution to $70^{\circ} \mathrm{C}$. When both phases had reached the desired temperature, removed both phases from the hot plate and added the aqueous phase slowly and with constant stirring to the oil phase. Stirred briskly and continuously until Congealed.

\section{METHOD OF PREPARATION OF} FINAL ANTIFUNGAL CREAM FORM: Accurately weighed quantity of Calotropis gigantea linn, Plant methanol extract was add in cream formulation and heated up to $70^{\circ} \mathrm{C}$ in a clean beaker. Weigh required quantity of ingredient Added under stirring. Adding of active plant Extract stir until it get solid cream form And then the mixture was cooled at room temp.
EVALUATION
OF
CALOTROPIS
GIGANTEA TOPICAL CREAM
FORMULATIONS: [18] 
The herbal cream was evaluated for various physicochemical parameters such as physical appearance (colour, Odour, and taste), Spreadability, viscosity, $\mathrm{pH}$, stability studies.

\section{ACCELERATED STABILITY STUDY:}

[19]

Stability studies for this present work was carried out at $40^{\circ} \mathrm{C} \pm 2{ }^{\circ} \mathrm{C} 75 \% \mathrm{RH}$ for the selected formulation for three months. The selected formulations were packed in Glass beaker. They were stored at $40^{\circ} \pm 2^{\circ} \mathrm{C} / 75 \pm 5 \%$ $\mathrm{RH}$ for 3 months in humidity chamber and evaluated for their physical appearance and various parameters at specified intervals of time.

\section{AGAR WELL DIFFUSION METHOD}

[20-22]: Agar well diffusion method: this method is commonly used to check the antimicrobial activity of plants or microbial extracts. Similarly to the procedure utilized in disk diffusion method, the agar plate surface is inoculated by spreading a volume of the microbial inoculum over all agar surfaces. Then, a hole with measurement across object of 6 to $8 \mathrm{~mm}$ is punched aseptically with a sterile plug borer or a tip and a volume standard drug (Ethambutol $60 \mathrm{mg} / \mathrm{ml}$ ), methanolic extract of Calotropis gigantea plant $(10 \mathrm{mg} / \mathrm{ml})$ and formulation optimize batch F6 $(1 \% \mathrm{w} / \mathrm{v})$ introduced in to the wall. Then agar plates are incubated for 24hr, under applicable conditions depending upon the microorganisms. The antimicrobial extracts of Calotropis gigantea fruit standard tuberculosis drug and formulation diffuses in the agar medium and inhibits the growth of the various microbial strains were used.

\section{RESULTS AND DISCUSSION: PRELIMINARY PHYTOCHEMICAL SCREENING:}

Capparis moonii fruits extracts showed the presence of secondary metabolites as in Table 1.

\section{THIN LAYER CHROMATOGRAPHY:}

Assessment of secondary metabolites were observed by TLC and showed in Table 2. In that $\mathrm{Rf}$ value are comparable with the standard.

\section{TOTAL PHENOLIC CONTENT:}

The phenolic content was calculated using the linear regression equation obtained from standard gallic acid graph $(\mathrm{r} 2=$ $0.998), y=0.0057 x+0.0113$. Among test extracts at concentrations $50 \mu \mathrm{g} / \mathrm{ml}$ and $100 \mu \mathrm{g} / \mathrm{ml}$, the total phenolic content was found to be $6.72 \pm 0.036$ and $8.56 \pm 0.109$ $\mathrm{mg}$ of $\mathrm{GA} / \mathrm{g}$ in methanol extract of Calotropis Gigantea plant.

\section{TOTAL FLAVONOID CONTENT:}

Flavonoid content was calculated using the linear regression equation obtained from standard quercetin graph (r2= 0.997), $\mathrm{y}=0.0077 \mathrm{x}-0.0149$. Among test extracts at concentrations $50 \mu \mathrm{g} / \mathrm{ml}$ and $100 \mu \mathrm{g} / \mathrm{ml}$, the total flavonoid content 
were found to be $7.10 \pm 0.141$ and $8.89 \pm$ $0.677 \mathrm{mg}$ of $\mathrm{QE} / \mathrm{g}$ in methanol extract of Calotropis Gigante plant.

\section{ANTIOXIDANT ACTIVITY STUDY:}

Evaluation of scavenging activity on

DPPH radicals:

$\%$ scavenging of DPPH $=\left(A_{\text {control }}-A_{\text {test }}\right)$

$$
\text { / } \mathbf{A}_{\text {control }} \times \mathbf{1 0 0}
$$

The methanolic extract of Calotropis gigantea, showed significant antioxidant activity as compared with the ascorbic acid Showed Table 3. The antioxidant activity of scavenging activity on DPPH radicals may due to the presence of flavonoids, tannins and phenol.

\section{EVALUATION OF TOPICAL CREAM}

FORMULATON: The evaluation of antifungal cream was evaluated on various parameters which was showed in the Table 3.

The topical cream formulations of

Calotropis Gigantea, methanolic extract batch F7, F8, F9 show satisfactory result in parameters such as colour and appearance, Spreadability and viscosity and $\mathrm{pH}$. Therefore, formulation F7 was selected for post stability evaluation.

\section{COMPARATIVE MICROBIAL}

\section{ASSAY:}

The antifungal evaluation study, performed by microbial assay in well plate method, which shows the active results against the fungi (C.albicans), as compared with standard Clotrimazole cream which is Antifungal, Antimicrobial cream.

\section{ACCELERATED STABILITY STUDY:}

Accelerated stability study was showed in Table 5 where total 3 month study was carried out for different parametesie. Colour and its appearance, Spreadiability, Viscosity and $\mathrm{pH}$ and there was acceptable change.

Table 1: Phytochemical screening of Capparis moonii fruits

\begin{tabular}{|c|c|c|c|c|c|c|}
\hline Sr. No. & constituents & PEE & EAE & EE & ME & HAE \\
\hline 1. & Sterols & + & + & - & - & - \\
\hline 2. & Alkaloids & - & - & + & + & + \\
\hline 3. & flavonoids & - & - & + & + & + \\
\hline 4. & Phenol \& Tannins & - & - & + & + & - \\
\hline 5. & Proteins & - & + & - & - & - \\
\hline 6. & Carbohydrates & - & - & + & + & + \\
\hline 7. & Glycosides & - & + & - & + & - \\
\hline
\end{tabular}

PEE-Petroleum ether extract, EAE-ethyl acetate extract, EE- ethanolic extract, ME- methanolic extract, HAEhydroalcholic extract; + Presence, - Absence 
Table 2: Thin layer chromatography of Capparis moonii fruits methanolic extracts

\begin{tabular}{|c|c|c|c|c|}
\hline Sr. No. & $\begin{array}{c}\text { Calotropis Gigantea } \\
\text { plant }\end{array}$ & $\begin{array}{c}\text { Samples } \\
\text { Developing solvents and } \\
\text { visualizing agents }\end{array}$ & $\mathbf{R}_{\mathbf{f}}$ values & TLC plate \\
\hline 1. & Methanolic extract & $\begin{array}{l}\text { Butanol: acetic acid: } \\
\text { water }(4: 2: 2) \text { visualizing } \\
\text { agents : Iodine chamber. }\end{array}$ & 0.61 & \\
\hline \multicolumn{5}{|c|}{ Comparative TLC with standard } \\
\hline 2. & $\begin{array}{l}\text { Sample (T)- } \\
\text { Methanol Standard } \\
\text { (S)quercetin }\end{array}$ & $\begin{array}{l}\text { Butanol : acetic acid : } \\
\text { water } \\
(4: 2.5: 1) \text { visualizing } \\
\text { agents: } \\
\text { AlCl }_{3} \\
\text { Observed in UV } \\
\text { chamber at } 360 \mathrm{~nm}\end{array}$ & $\begin{array}{l}\mathrm{S}-\mathbf{- 0 . 7} \\
\mathrm{T}-\mathbf{0 . 7}\end{array}$ & \\
\hline
\end{tabular}

Table 3: Effects of test extracts on \% DPPH inhibition

\begin{tabular}{|c|c|c|}
\hline \multirow{2}{*}{$\begin{array}{c}\text { Conc. } \\
(\mu \mathrm{g} / \mathrm{ml})\end{array}$} & \multicolumn{2}{|c|}{ \% scavenging activity on DPPH radicals } \\
\cline { 2 - 3 } & Ascorbic acid & ME \\
\hline 25 & $\mathbf{3 2 . 1 4} \pm \mathbf{0 . 6 3}$ & $\mathbf{1 7 . 4 8} \pm \mathbf{0 . 2 9}$ \\
\hline 50 & $48.37 \pm 0.66$ & $\mathbf{3 6 . 4 5} \pm 1.88$ \\
\hline 75 & $68.91 \pm 0.62$ & $45.76 \pm 0.61$ \\
\hline 100 & $86.77 \pm 1.05$ & $68.94 \pm 1.13$ \\
\hline 125 & $96.27 \pm 0.55$ & $\mathbf{7 6 . 8 6} \pm \mathbf{0 . 4 5}$ \\
\hline
\end{tabular}

Values expressed as Mean \pm SD, $n=3$ 
Table 4: Colour and appearance, spreadability and viscosity and $\mathrm{pH}$ of topical cream formulations

\begin{tabular}{|c|c|c|c|c|}
\hline Formulation & $\begin{array}{c}\text { Colour and } \\
\text { appearance }\end{array}$ & $\begin{array}{c}\text { Spredability } \\
(\mathbf{C m} / \mathbf{s e c})\end{array}$ & Viscosity (cp) & pH \\
\hline$F_{1}$ & Olive green & $\mathbf{1 1 . 7 6} \pm \mathbf{0 . 0 7 1}$ & $\mathbf{8 6 0 1 0} \pm \mathbf{2 0 5 . 5}$ & $\mathbf{5 . 3 5} \pm \mathbf{0 . 0 3 5}$ \\
\hline$F_{2}$ & Olive green & $\mathbf{1 3 . 3 2} \pm \mathbf{0 . 0 8 2}$ & $\mathbf{9 8 8 0 0} \pm \mathbf{1 5 2 . 7}$ & $\mathbf{5 . 3 1} \pm \mathbf{0 . 0 1}$ \\
\hline$F_{3}$ & Olive green & $\mathbf{1 2 . 2 0} \pm \mathbf{0 . 1 0 3}$ & $\mathbf{3 7 3 6 4} \pm \mathbf{1 1 5 . 5 6}$ & $\mathbf{5 . 5} \pm \mathbf{0 . 0 5}$ \\
\hline$F_{4}$ & Olive green & $\mathbf{1 5 . 6 5} \pm \mathbf{0 . 1 1 3}$ & $\mathbf{2 7 5 1 6} \pm \mathbf{1 0 1 . 8}$ & $\mathbf{5 . 2 2} \pm \mathbf{0 . 0 4}$ \\
\hline$F_{5}$ & Olive green & $\mathbf{1 4 . 9 9} \pm \mathbf{0 . 1 4 5}$ & $\mathbf{8 6 0 1 3} \pm \mathbf{2 5 5 . 6 8}$ & $\mathbf{5 . 3 2} \pm \mathbf{0 . 0 5}$ \\
\hline $\mathrm{F}_{6}$ & Olive green & $\mathbf{1 3 . 5 2} \pm \mathbf{0 . 0 7 8}$ & $\mathbf{9 9 8 6 1} \pm \mathbf{1 5 3 . 8}$ & $\mathbf{5 . 4 8} \pm \mathbf{0 . 1 2}$ \\
\hline $\mathrm{F}_{7}$ & Olive green & $\mathbf{1 2 . 5 5} \pm \mathbf{0 . 0 2 7}$ & $\mathbf{3 7 5 1 6} \pm \mathbf{1 1 6 . 8}$ & $\mathbf{5 . 2 3} \pm \mathbf{0 . 0 8}$ \\
\hline $\mathrm{F}_{\mathbf{8}}$ & Olive green & $\mathbf{1 1 . 7 8} \pm \mathbf{0 . 0 6 8}$ & $\mathbf{3 6 8 0 0 9} \pm \mathbf{1 6 5 . 2}$ & $\mathbf{5 . 3 5} \pm \mathbf{0 . 0 6}$ \\
\hline $\mathrm{F}_{\mathbf{9}}$ & Olive green & $\mathbf{1 5 . 5 1} \pm \mathbf{0 . 3 2 7}$ & $\mathbf{3 7 3 6 4} \pm \mathbf{1 1 5 . 2 3}$ & $\mathbf{5 . 5 5} \pm \mathbf{0 . 0 5}$ \\
\hline
\end{tabular}

Values expressed as Mean \pm SD, $n=3$

Table 4: comparative microbial assay in various cultures

\begin{tabular}{|c|c|c|c|}
\hline Sr. No. & Content in well plate & Concentration & Zone of inhibition (cm) \\
\hline 1. & Methanol Extract & $\mathbf{0 . 1}$ g/ml & $2.9 \mathrm{~cm} \pm \mathbf{0 . 0 1 6}$ \\
\hline 2. & Cream Formulation & $10 \% \mathrm{w} / \mathrm{v}$ & $2.7 \mathrm{~cm} \pm 0.02$ \\
\hline 3. & Std.Clotrimazole cream & $1 \% \mathrm{w} / \mathrm{v}$ & $2.6 \mathrm{~cm} \pm 0.052$ \\
\hline
\end{tabular}

Values expressed as Mean $\pm \mathrm{SD}, \mathrm{n}=3$

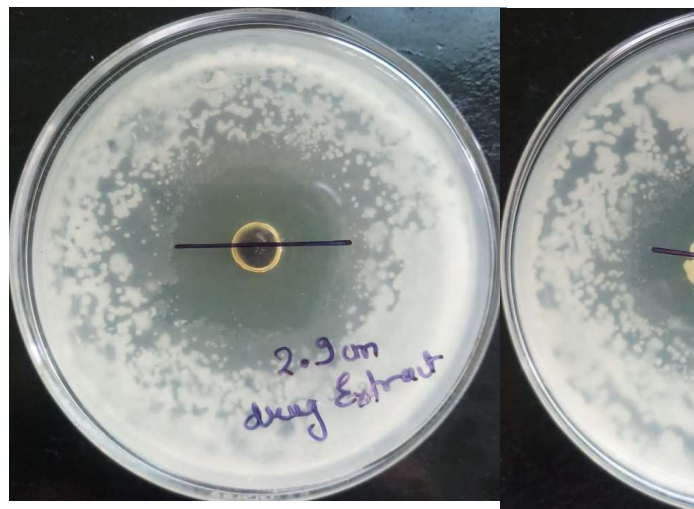

(a)

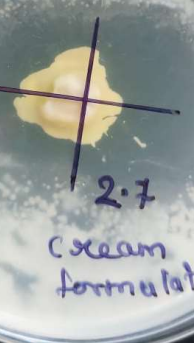

(b)

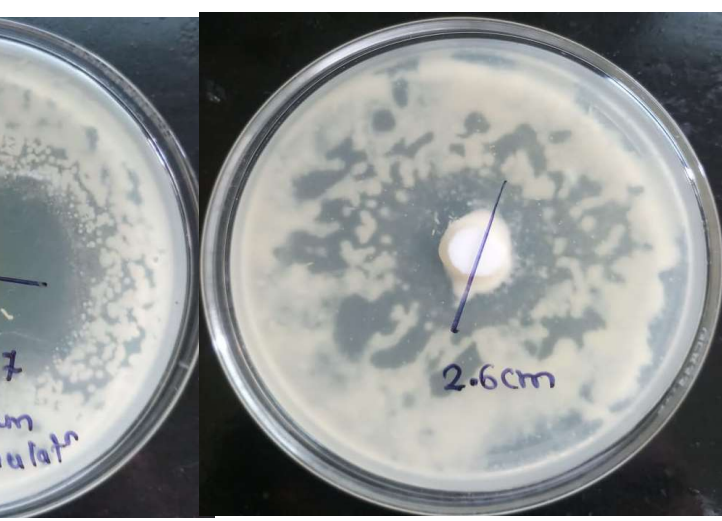

(c)

Figure 1: Showing the zone of Inhibition in (a) plant extract (b) Cream formulation (c) Std. clotrimazole cream

Table 5: Accelerated stability study of optimise batch F7

\begin{tabular}{|c|c|c|c|c|}
\hline \multirow{2}{*}{ PARAMETERS } & \multicolumn{4}{|c|}{ STROAGE (IN MONTH) } \\
\cline { 2 - 5 } & $\begin{array}{c}\text { INITIAL } \\
\text { 0 Day }\end{array}$ & $\begin{array}{c}1^{\text {ST }} \\
\text { MONTH }\end{array}$ & $2^{\text {nd }}$ MONTH & $\begin{array}{c}3^{\text {rd }} \\
\text { MONTH }\end{array}$ \\
\hline Colour and appearance & NC & NC & NC & NC \\
\hline Spreadability (cm/sec) & $\mathbf{1 4 . 2 0} \pm 0.103$ & $15.65 \pm 0.113$ & $16.78 \pm 0.021$ & $16.65 \pm 0.113$ \\
\hline Viscosity (cp) & $\mathbf{2 9 5 1 6} \pm 101.8$ & $\mathbf{2 9 5 1 6} \pm 101.8$ & $\mathbf{3 2 3 6 4} \pm 115.56$ & $\mathbf{3 7 3 6 4} \pm 115.56$ \\
\hline pH & $\mathbf{5 . 5 5} \pm \mathbf{0 . 0 5}$ & $\mathbf{5 . 2 5} \pm \mathbf{0 . 0 5}$ & $\mathbf{6 . 0 1} \pm \mathbf{0 . 1 6}$ & $\mathbf{5 . 8 1} \pm \mathbf{0 . 2 8}$ \\
\hline
\end{tabular}

Values expressed as Mean $\pm \mathrm{SD}, \mathrm{n}=\mathbf{3}$

\section{SUMMARY}

The main objective of this study was to screen the Calotropis Gigantea Linn, extracts for its anti-fungal activity.The successive extraction was carried out by using polar to non- polar solvent. Percent yield of Calotropis Gigantea, plant extract Ethanol (2.6), Methanol (3.4), Hydro alcoholic (3.2) extract was found better as compared to other extracts. Preliminary 
phytochemical screening showed the various secondary metabolites obtained in Calotropis Gigantea extracts.TLC fingerprinting demonstrated the presence of various secondary metabolites and flavonoid content in Calotropis Gigantea extracts. Methanolic extract showed presence of phenol content was found to be $6.78 \pm 0.036$ and $8.56 \pm 1.69 \mathrm{mgof} \mathrm{GA} / \mathrm{g}$ and flavonoid content was found to be 7.10 \pm 0.141 and $8.89 \pm 0.677 \mathrm{mg}$ of QE/g.If we compare this studies with the previously reported research paper we will observed that it may have the more phenol and flavonoid content in stem, and flower as compared to Calotropis gigantea fruit, and leaves.

The anti-oxidant study shows that scavenging activity on DPPH radicals was found to be higher inhibition of DDPH was exhibited by methanol extract $76.86 \pm 0.45$ was compared to ascorbic acid. Methanolic extracts shows the antioxidant activity. Calotropis gigantean plant methanol extract shows presence of various $\mathrm{C}-\mathrm{H}$ bending $\mathrm{C}=\mathrm{O}$ stretching and sec. aromatic compounds, in FTIR Interpretation.

The liquid oral formulations and evaluations of Calotropis Gigantea, methanolic extracts were prepared showed good elegance. The Topical cream evaluated for measurement of colour and appearance, spreadability and viscosity and
$\mathrm{pH}$ among 9 batches F7 showed satisfactory results. The final formulation found to have olive Green colour, spreadability $12.55 \pm 0.027 \mathrm{~cm} / \mathrm{sec}$, viscosity $37516 \pm 311.8 \mathrm{cp}$ and $\mathrm{pH} 5.23 \pm 0.08$. The results of stability study of the final syrup reveal that no changes were noticed in all the tested physicochemical parameter during 3 month in at $40^{\circ} \mathrm{C} \pm 2{ }^{\circ} \mathrm{C} 75 \% \mathrm{RH}$. Comparative microbial assay by well diffusion method shows satisfactory results in fungal strain C.albicans. The methanolic extract and formulation inhibits the growth of fungal strain as compare with standard antifungal topical drug. The methanolic extract of Calotropis gigantea, plant exhibit some concentration of flavonoids like rutin and qurcetin they shows antifungal activity as well as the phytoconstituents like phenol, tannins, sterols, alkaloids. The antioxidant has been attributed by the presence of above mention phytoconstituents and comparing with little bet similar strain of bacteria shows good results. Therefore, methanolic extracts of Calotropis gigantea Linn, plant have likely to have potential activity against C.albicans, in the treatment of Candidiasis.

CONCLUSION: The methanolic extracts of Calotropis gigantea, plant extracts it shows the presence of phenolic and flavonoid content in the methanolic extracts and it may active components 
shows Antifungal activity. Phenolic compounds as well as flavonoids are wellknown as antioxidant may help to reduction of toxic side effects in therapy and reduced oxidative stress which associated with severe skin infection like candidiasis. The comparative microbial study with different fungi and bacteria shows good results and thus herbal cream formulation of Calotropis giganteacan be used to cure the candidiasis. The possible mechanism of action at cellular level may become a useful approach to develop natural bioactive products. The topical cream formulations and evaluations of Calotropis Gigantea, methanolic extracts were prepared showed good elegance and Antifungal activity. From this study, we have observed that Calotropis gigantea linn, plant have potential Antifungal and antimicrobial activity, and can used for the treatment of fungal infection.

\section{REFERENCES}

[1]S Sarkar, R Chakraverty; Calotropis gigantea Linn. - A Complete Busket of Indian Traditional Medicine, A. Int. J. Pharm. Res. Sci., 2014, 02(1), 717.

[2]Jagtap V A, Md Rageeb Md, Usman, Salunkhe P S, Gagrani M B Anti-Inflammatory activity of calotropis gigantea Linn, leaves in vitro models, International Journal of Current Pharmaceutical Review and Research.2010 Volume 1(2) 15.

[3] Singh S, Majumdar DK, Singh JV, Govil JV, Eds. Recent progress in medicinal plant, phytochemistry and pharmacology -2, Stidium Press, LIC USA, 2003; 2: 2-3.

[4]M.R Habib; MR Karim, Antimicrobial and Cytotoxic Activity of Di-(2-ethylhexyl) Phthalate and Anhydrosophoradiol3-acetate Isolated from Calotropis gigantea (Linn.) Flower. Mycobiology 2009; 37(1):31-36.

[5]Saiman L, Ludington E, Dawson JD, Patterson JE, Rangel-Frausto S, Wiblin RT, Blumberg HM, Rinaldi M, Edwards JE, Wenzel RP.; Risk factors for Candida species colonization of neonatal intensive care unit patients.; The Pediatric Infectious disease Journal. 2001 Dec 1; 20(12): 1119-1124.

[6]Owen Kramer,; Types of fungal infections and there treatment in genera, (P.HD), : dept. of microbiology and cytology: 07 Oct 2020: 110-122.

[7]Nwabueze TU, Okocha KS. Extraction performances of polar and non-polar solvents on the 
physical and chemical indices of

African breadfruit (Treculia

africana) seed oil.African Journal

of Food Science. 2008 Oct 31; 2(10): 119-125.

[8]Khandelwal K. Practical pharmacognosy. Pragati Books Pvt. Ltd.; 2008 Sep 7.3(5): 102-106 .

[9] Gujjeti RP, Mamidala E. Phytochemical analysis and TLC profile of Madhuca indica inner bark plant extract. International Journal of Scientific \& Engineering Research. 2013; 4(10):1507-1510.

[10] Quazi, S. Mathur, K. Arora, S. Calotropis procera: an overview of it phytochemistry and pharmacology. Indian J. Drugs, 2013, 1, 63-69.

[11] Thomas Jim, Sureshkumar M,; phytochemicals: extraction, isolation and identification of bioactive compounds from calotropis gigantea (linn) - erukku; Journal of Emerging Technologies and Innovative Research; January 2019,; Volume 6, Issue 1.659-668.

[12] Pathak AK, Argal A, Analgesic activity of Calotropis gigantea flower. Fitoterapia 2007; 78(1):4042.

[13] Sushant A, BaniyaMK, Danekhu K, Kunwar P, Gurung
R. and Koirala R. Total phenolic content, Flavonoid content, and Antioxidant potential of wild Vegetables ;Plants 2019, 8, 96;212.

[14] Singh N, Jain NK, Kannojia P, Garud N, Pathak AK, Mehta SC, In vitro antioxidant activity of Calotropis gigantea hydroalcohlic leaves extract. Der Pharmacia Lettre 2010; 2(3):95- 100.

[15] Ramamurthy N,; FTIR Spectroscopic analysis of plant C.Gigantea from an industrial village; National institute of technology; jan 2007;502-505.

[16] Mehta RM.; text book of pharmaceutics-I, Semisolid dosage form; Vallabh Prakashan; 2002; 101-104.

[17] Ana Simoes, Francisco Veiga, et al: A Development of topical Cream formulation Based on the quality By Design Approach,: J pharma Sci, oct 18; 107(10) -26532662.

[18] Mounyerbalouirin : methods for invitro evaluation of antifungal activity; J Pharm Anal. 2016 Apr; 6(2): 71-79.

[19] Pawar V, Sujata S; Formulation and evaluation of dental gel containing essential oil of coriander 
Against oral pathogens; Int. Res. J.

Pharm,; 2013; 4 (10); 105-109.

[20] Lopez-Oviedo E, Aller AI, Martín

$\mathrm{C}$; Evaluation of disk diffusion method for determining Posaconazole susceptibility of filamentous fungi,; comparison with CLSI broth microdilution method Antimicrobial Agents Chemothe R.; Europeon J. of Microbio. Research.; 2006: 50110.

[21] Kumar G, Karthik L, Bhaskara Rao $\mathrm{KV}$, In vitro anti-Candida activity of Calotropis gigantea against clinical isolates of Candida. Journal of Pharmacy Research 2010; 3(3): 539- 542 .

[22] SK. Screening methods in the study of antimicrobial properties of medicinal plants. International Journal of Biotechnology and Research. 2012. 2(1): 1-35. 